\title{
STRATEGICKÉ PLÁNOVÁNÍ OBCÍ A MĚST: NOVÉ P̌́ÍSTUPY A CESTY K JEHO ZEFEKTIVNĚNÍ
}

\section{STRATEGIC URBAN PLANNING: NEW APPROACHES AND THE WAYS HOW TO STREAMLINE IT}

\section{DOC. RNDR. JIŘí JEŽEK, PH.D.}

\author{
Středisko pro výzkum regionálního rozvoje/ Katedra |Centre for Regional Development Research/ \\ geografie Department of Geography \\ Fakulta ekonomická Faculty of Economics \\ Západočeská univerzita v Plzni $\mid$ University of West Bohemia \\ $\triangle$ Husova 11, 30614 Plzeň, Czech Republic \\ E-mail:jezekji@kge.zcu.cz
}

\begin{abstract}
Anotace
Příspěvek se zabývá kritickou analýzou strategického plánování českých měst a hledá cesty kjeho zefektivněni. Využivá poznatky z empirického výzkumu 384 měst, které jsou zasazeny do kontextu nových poznatků z oblasti strategického výzkumu (policy analysis, emergentni strategie aj.). Dochází kzávěru, že úkolem plánovacího procesu neni pouze navrhovat strategie a projekty, ale také organizačni strukturu, jak o nich bude rozhodováno, jak budou realizovány a evaluovány. Navrhuje, aby byla klíčová pozornost věnována nadmistni spolupráci obci a měst voblasti strategického plánování.
\end{abstract}

\section{Klíčová slova}

Strategické plánování, rozvoj měst a regionů, Česká republika

\section{Annotation}

The paper deals with a critical analysis of strategic planning of the Czech towns and it looks for the ways how to streamline it. It exploits results from the empirical research of 348 towns which are included in a context of new knowledge from a strategic research sphere (policy analysis, emergency strategies etc.). There is a summary that the role of the planning process is not only proposing strategies and projects, but also the organisational structure, how it will be decided about them, how they will be realized and evaluated. It suggests pay a significant attention to supra-local cooperation between municipalities and the towns in the strategic planning sphere.

Key words

Strategic planning, strategic urban and regional development, Czech Republic

JEL classification: $02, R 5$

\section{Úvod}

Města představují významný potenciál současného a budoucího rozvoje Evropy (Lipská charta 2007, Toledská deklarace 2007 nebo Územní agenda EU 2020). Urbánní dimenze se stává stále významnější součástí kohezní politiky EU. Města dnes čelí nejenom finanční a ekonomické krizi, ale také dalekosáhlým ekonomickým (globalizace, deindustrializace, rozvoj informačních a komunikačních technologií), sociálním (stárnutí obyvatelstva a jeho úbytek, růst nezaměstnanosti, chudoby a sociální diferenciace, individualizace životních stylů atd.), politickým (změna chápání státu a jeho funkcí, decentralizace, nové formy vládnutí a řízení veřejného sektoru) a environmentálním (změna klimatu) změnám. A to v situaci, kdy je stále obtížnější dosáhnout změny a kdy městské správy musejí přijímat restriktivní opatření a „dosahovat více se stále menším množstvím prostředkư“. Jak v teorii, tak 
především v praxi se hledají nové strategické a integrované přístupy $\mathrm{k}$ městskému rozvoji, vycházející z principu spolupráce, partnerství a koordinace, které povedou kdosahování synergických a multiplikačních efektı̊.

Po období projektově-orientovaného plánování (80. a 90. léta 20. století), které vedlo k inkrementalizaci a fragmentaci koncepčních př́stupů $\mathrm{k}$ rozvoji měst, $\mathrm{k}$ neefektivnímu osamostatňování projektů a $\mathrm{k}$ upřednostňování spíše krátkodobých a individuálních zájmů, se v posledních přibližně deseti letech (nejenom pod vlivem současné krize) hledají nové, promyšlené (chytré) a integrující př́stupy. Podle některých teoretiků dochází $\mathrm{k}$,renesanci strategického plánováni“ či ke „strategickému obratu“ (Faludi 2000; Healey 2006; Archibugi 2008 aj.). Jiní takové názory zpochybňují s odkazem, že pro taková tvrzení chybí empirické důkazy. (Selle 2006; Newmann 2008; Wiechmann 2008 aj.)

Strategické plánování v kontextu rozvoje měst je dnes celosvětově široce diskutovaným tématem. Samotný pojem je přitom mnohoznačně interpretován a rozporuplně hodnocen. Diskuse o strategickém plánování obcí, měst a regionů má v jednotlivých zemích EU značně odlišný kontext a průběh, takže existuje velké množství přístupů a modelů. Blíže se touto problematikou zabýváme v článku nazvaném „Plánování rozvoje měst a regionu. Vývoj teoretických přistupü“. (Ježek, 2011a) Přestože existují $\mathrm{v}$ rámci Evropské unie snahy o sbližování plánovacích systémů, tak mezi jednotlivými zeměmi existující poměrně značné rozdíly, odrážející jak politické a kulturní tradice daných zemí, tak jejich právní systémy a ekonomické a sociální priority.

Diskuse o strategickém plánování v rozvoji měst má silně normativní charakter. Navíc, jak upozorňuje Newmann, tak postrádáme kritické empirické výzkumy o tom, nakolik strategické plánování pomáhá městům s řešením jejich problémů, resp. je schopno „,rídit strukturální změny ve městech“ (Newmann 2008).

Strategická orientace a integrace je vedle podpory trhu, kvalitních projektů a snadnější prrípravy a realizace projektů jedním ze čtyř základních principů, z nichž bude vycházet regionální (kohezní) politika EU po roce 2013. Uplatnění uvedených principů má zajistit efektivní využívání strukturálních fondů EU v nadcházejícím programovacím období 2014-2020.

\section{Cíl práce a metody}

Cílem tohoto příspěvku je kritické zhodnocení současné situace strategického plánování měst a obcí v České republice a diskuse některé návrhů na jeho zefektivnění. Východiskem našich úvah jsou nejenom výsledky empirického výzkumu, do něhož bylo zahrnuto 384 českých měst (publikované v článku Ježek 2011b), ale také nejnovější poznatky o strategickém plánování měst a regionů, obsažené v publikacích významných teoretiků, uvedených na konci tohoto článku.

\section{Strategické plánování v podmínkách českých měst a obcí a navrhované cesty k jeho zefektivnění}

Strategické plánování není českým městům neznámé. Podíváme-li se na danou problematiku z dlouhodobého (historického) pohledu, tak po roce 1989 mělo jakékoliv plánování pejorativní nádech. Důvodem byly nejenom negativní historické zkušenosti, ale také odpor vlivných ekonomických liberálů. Specifikem československého, resp. českého plánovacího systému navíc je, že se historicky zformovaly dva plánovací subsystémy. Socioekonomické plánování (dříve nazývané oblastní) a územní plánování, které má nepochybně delší a bohatší tradici. Tato dvoukolejnost nebo dichotomie plánování přetrvává dodnes, i když se na počátku 90. let 20. století zdálo, že převezmeme německý model prostorového plánování, který obsahuje jak územně-technické, tak socioekonomické (rozvojové) aspekty. Tato dichotomie přináší řadu problémů, které by staly za podrobnější analýzu.

V posledních letech vzniklo několik empirických studií, které se zabývají analýzou uplatnění strategického plánování v podmínkách českých měst a regionů (za všechny můžeme uvést např. Ježek 
2011b). Na jedné straně existuje velké množství měst, která si pořizují strategické plány (podle našich zjištění cca 54\% měst, viz Ježek 2011b) a široká nabídka postupů a metodik, jak takové strategické plány pro města a regiony vytvářet, realizovat a evaluovat. Jenom v současné době (březen 2013) pro potřeby MMR vzniká 7 takových metodik. Mezi nimi např. „Elektronická metodická podpora tvorby rozvojových dokumentů obcí", realizovaná v rámci projektu ESF firmami GaREP, s r.o. a eRozvoj.cz. Na druhé straně mnozí upozorňují, že se strategickým plánováním není v České republice vše v pořádku a že plánovací realita neodpovídá ani teoretickým předpokladům, ani politickým očekáváním. Někteří označují současný stav jako ,plánování pro plánováni“" a ptají se, proč strategické plánování měst a regionů v České republice nefunguje a nepřináší očekávané výsledky?

Z hlediska pojetí strategického plánování, jak ukazují naše výzkumy, tradičně převažuje racionalistický př́stup, resp. lineární model tvorby rozvojových strategií. Strategie jsou chápány jako dlouhodobé plány. Východiskem jsou podrobné analýzy. Strategický plánovací proces se chápe jako sled jednotlivých plánovacích kroků. Po analýze, která většinou vyúst’uje ve SWOT analýzu, se stanovují vize a strategické cíle. Z nich jsou následně odvozena opatření. Poté nastává realizační a následně evaluační fáze. Evaluace strategický plánů měst a regionů je jednou z nejslabších stránek plánovacího procesu. Mnohé strategické plány ani nepředpokládají, že by měly být vyhodnocovány.

Zmíněný přístup se také uplatňuje při řešení již zmíněného projektu „Elektronická metodická podpora tvorby rozvojových dokumentů obci'“. Jeho cílem je zvýšit efektivitu plánovacího systému tím, že řešitelé poskytnou, zejména malým obcím, softwarový nástroj s on-line př́stupem, který jim usnadní tvorbu rozvojových koncepcí. V rámci řešení tohoto projektu (na objednávku MMR) byla provedena „Analýza současného plánování rozvoje na obecní úrovni“. Ve výstupu označeném I.a2 se v návrhové části uvádějí následující ,základní východiska pro zkvalitnění ř́izení rozvoje obcí“ (MMR 2012, s. 41):

- Strategické plánování rozvoje obcí je v právním řádu ČR upraveno minimální měrou, a to pouze v dilč̌ich oblastech. Procesni úprava strategického plánováni neni téměr žádná. Nezbytným krokem je proto jednoznačné zakotveni strategického plánováni obci v právním $\check{r a ́ d u ~ C ̌ R ~ a ~ s t a n o v e n i ~ z a ́ k l a d n i c h ~(m i n i m a ́ l n i c h) ~ p l a ́ n o v a c i c h ~ p r o c e s u ̊ ~ n a ~ o b e c n i ́ ~ u ́ r o v n i ~ a ~}$ dořešeni (horizontálnich i vertikálních) vazeb v rámci plánováni veřejné správy.

- Metodická podpora plánováni obci je nedostatečná a chybi ucelený a jednotný odborný plánovaci rámec. Je zapotřebi zpracovat metodické manuály a vytvořit podpưrné metodické prostředky k plánováni obci a sladit názory odborné veřejnosti.

- (...) Je třeba posilit vzdělávací aktivity v oblasti strategického plánování.

Autoři zmiňované studie jako klíčový problém uvádějí neukotvenost strategických dokumentů na obecní úrovni, přičemž se odvolávají na názory představitelů zkoumaných obcí (dotázáno celkem 885 obcí) a představitelů tří pilotních krajských úřadů, že „vzhledem $k$ tomu, že v legislativě $\check{C} R$ doposud není definován zpưsob zpracováni koncepčních dokumentů na úrovni obcí a ani jejich závaznost, nelze tyto dokumenty prílišs využivat v praxi krajských úřadů voblasti plánování rozvoje území (zejména kvůli nevyváženosti informaci v těchto dokumentech obsažených“. Dodávají, že „prrípadné zakotvení strategických dokumentů na úrovni obci v legislativě by krajské úr̆ady privitaly zejména z dưvodu možnosti komplexního plánováni rozvoje území na základě konkrétních záměrù obci“.. K tomu na jiném místě dodávají, že jim , není znám dưvod, proč stejnou povinnost [myšleno zákonnou povinnost pořizovat programy rozvoje pro všechny obce] zákonodárce neprenesl i na obce". (MMR 2012, s. 43) V důsledku toho navrhují ,implementovat do novely zákona o podpoře regionálního rozvoje povinnost všech územně samosprávných celků plánovat svi̊j rozvoj, včetně sankcí, a zformulovat své cile a cesty k nim vedouci do podoby závazného strategického rozvojového dokumentü“. (MMR 2012, s. 44) Dále doporučují minimální povinný obsah strategického rozvojového dokumentu (minimální obsah by přitom měl být výstupem jimi řešeného projektu). 


\section{Nové přristupy ke strategickému plánování měst a regionů - výzva pro české obce a města}

Tradiční představa strategického plánování je jednoduchá; stačí vybrat správnou strategii a výsledek je zajištěn. Jak v teorii, tak i praxi stále převažuje představa plánování jako technokratického procesu plánování jako vědeckými poznatky vedené zpracování informací, pomáhající řešit společenské problémy a dosahovat stanovených cílů. Již v 70 . letech 20 . století se $\mathrm{v}$ rámci policy analysis (politických věd) rozvinul nový koncept „politického plánováni“" (plánování jako součást veřejné politiky, viz např. Niklas Luhmann, 1971), který se zabývá u nás značně opomíjenými institucionálními otázkami plánovacích procesů. Institucionální zakořenění strategického plánování (formy jeho organizace, postupy, formy zprostředkování informací a zájmů, způsob rozhodování, participace veřejnosti atd.) totiž významným způsobem ovlivňují efektivitu plánovacích procesů.

Nejenom naše poznatky ukazují, že strategické plány dnes ztrácejí normativní charakter a roste význam plánování jako procesu, který umožňuje komunikaci, kolektivní učení, vytváří konsensus a mění rutinní postupy. Jak říká přední evropský teoretik A. Faludi, tak ,strategický plán dnes není ničím více, než jenom okamžitou reflexí dohody mezi aktéry“. (Faludi 1999, s. 138) V tomto pojetí se již de facto nejedná o plánování, ale o strategický management rozvoje měst a regionů.

Tradičně se tvorba strategií chápe jako racionální plánovací proces, jehož východiskem je podrobná analýza a hierarchické řízení. Kritikové tohoto pojetí, opírající se o nové poznatky z oblasti strategického výzkumu (hlavně o práce H. Mintzberga) upozorňují na omezenou racionalitu velkého množství většinou spontánně jednajících aktérů a tvrdí, že v praxi se více realizují strategie neplánované, které se časem vynořují (emergentní strategie). Tvorbu strategií bychom proto měli chápat jako integrovaný a nepřetržitý proces, kde strategie vznikají ze zdola nahoru, prostřednictvím procesů kolektivního učení a adaptace. Není proto účelné vytvářet pouze vědomé strategie, ale spíše podporovat procesy strategického učení, a tak vytvářet předpoklady pro vznik nových emergentních strategií. Tvorbu rozvojových strategií je proto zapotřebí chápat spíše jako adaptační proces, který se odehrává v konkrétním ekonomickém, sociálním a politickém prostředí, prričemž strategie jsou výsledkem rozhodnutí klíčových aktérů (veřejných i soukromých) a nikoliv představ plánovačů či akademiků. Strategií tudíž není pouze to, co města plánují v budoucnosti dělat, ale také to, co skutečně dělají. Abychom $\mathrm{v}$ chování měst a jejich aktérů dokázali strategický přístup rozpoznat, musíme podle Mintzberga provést retrospektivní analýzu klíčových rozhodnutí a na základě nich strategické chování rekonstruovat. (Mintzberg 2003; Ježek a kol. 2007; Wiechmann 2008 aj.)

Doporučení vyplývající z „Analýzy současného plánování rozvoje na obecní úrovni“ (MMR 2012) jsou v kontextu výše uvedených nových poznatků a prŕstupů tudíž značně diskutabilní. V citované studii není ani náznak kritičnosti (pochybnosti) nebo zmínka o jiných, než prosazovaných řešeních. V české praxi přitom převažuje značná skepse ohledně uplatnění jakýchkoliv koncepčních přístupů, včetně strategického plánování. Mnohé obce a města si sice strategické plány pořizují (převažuje účelový motiv možnosti čerpání dotací z EU nad vnitřní potřebou koordinovat rozvojové aktivity), mnohé se jimi neřídí, neaktualizují je, ani je nevyhodnocují. (Ježek 2011b) Navíc zkušenosti ze sousedního Slovenska, kde existuje zákonná povinnost obcí a měst pořizovat si „programy sociálního a ekonomického rozvoje“ jsou takové, že pouze $10 \%$ největších měst s nimi pracuje, $40 \%$ je vůbec neaktualizuje a $50 \%$ je nemá a nepotřebuje (ústní sdělení pracovníka ministerstva dopravy a regionálního rozvoje na konferenci v Banské Bystrici dne 18.10.2012).

Podle našeho názoru je zapotřebí reflektovat nové poznatky a přistupovat ke strategickému plánování kriticky a chytře hledat možnosti jeho praktického uplatnění.

Předně je zapotřebí strategické plánování obcí, měst a regionů začít chápat jako v podstatě nekončící proces. Nikoliv jako jednorázovou tvorbu dlouhodobých plánů. O účelnosti strategického plánování v rozvoji obcí, měst a regionů nepochybujeme, ale řešením není ani povinnost všech obcí a měst si takové dokumenty pořizovat, ani nezbytnost zpracovávat je podle jednotné metodiky! Takové úvahy 
neodpovídají současným poznatkům plánovacích věd. Uplatňování takových byrokratických přístupů (povinnost pro všechny, jednotný postup zpracování) jak ukazují např. německé poznatky z období plánovací euforie na přelomu 60. a 70. let 20. století, vede $\mathrm{k}$ tomu, že se $\mathrm{z}$ plánovacího procesu vytrácejí tolik potřebné inovace a kreativita.

Již dnes je problémem, že strategické plány mnohých obcí a měst jsou čistě formální a podobají se jako vejce vejci (poradenské firmy při jejich zpracování často nereflektují odlišné rozvojové předpoklady jednotlivých obcí a měst) anebo obsahují tolik priorit a opatření, jako by dané obce a města disponovaly neomezenými zdroji, takže je otázkou, nakolik jsou takové strategie reálné.

Rostoucí prostorová mobilita lidí (na jednom místě bydlí, na jiném pracují, nakupují anebo tráví volný čas) vede $\mathrm{k}$ tomu, že dostupnost a požadovaná kvalita mnohých veřejných služeb, zvláště ve venkovských územích, je na obecní úrovni neřešitelná. Také nedostatečné finanční zdroje a stále klesající př́ijmy obecních rozpočtů malých obcí a měst (nejenom v důsledku současné ekonomické a sociální krize) vedou $\mathrm{k}$ tomu, že obce a města jsou de facto okolnostmi donucena vzájemně spolupracovat. Jedná se o významný fenomén, nebot' v České republice existuje značný počet velmi malých obcí bez odpovídajících rozvojových zdrojů a perspektiv.

V této souvislosti je zapotřebí posílit především nadmístní (mikroregionální) spolupráci obcí a měst v oblasti strategického plánování. Je nutné se také zabývat institucionálními, resp. organizačními otázkami takového strategického plánování a hledat odpovědi na otázky: kdo má být nositelem plánovacích kompetencí? Jak vytvářet taková plánovací sdružení? Na jakém organizačním principu? Na principu dobrovolnosti sdružování (zdola nahoru) nebo využijeme obvody obcí s přenesenou působností? Jak se budou jednotlivé obce a města demokraticky podílet na tvorbě, schvalování, realizaci a evaluaci společných strategií? Budou si taková plánovací sdružení budovat vlastní znalostní báze a vytvářet pozice profesionálních plánovačů nebo budou nadále využívat komerčních služeb poradenských organizací? Odpovědi na uvedené otázky je přitom zapotřebí hledat prostřednictvím otevřené diskuse nad alternativními modelovými řešeními.

\section{Závěr}

Tradiční představa o strategickém plánování, jak jsme již uvedli, je velmi jednoduchá. Stačí provést analýzu, vybrat správnou strategii a úspěch je zajištěn. Ve skutečnosti jsme v celé Evropě svědky dlouhodobé krize plánování rozvoje měst a regionů, které díky slábnoucí institucionální pozici má stále menší vliv na realizovaná rozvojová opatření. „,̌́idici potenciál“ strategického plánování se i v zemích s vyspělejší plánovací kulturou, než je ta česká (např. v Německu nebo Francii), ukazuje jako značně omezený. Uplatňování tradičních byrokratických př́stupů není cestou ke zefektivnění plánovacího systému. Je nutné reflektovat nejnovější poznatky z oblasti strategického výzkumu a primárně se zabývat jeho organizační a koordinační funkcí. (srovnej např. Albrechts 2004; Archibugi 2008 aj.)

Strategické plánování měst bychom měli chápat jako „sociální proces, na němž participuje velké množství lidí v různých institucionálních vztazich a pozicích, kteří navrhují společný postup, obsah a strategii, jak ř́dit prostorové změny“. (Healey 2007) Úkolem plánovacího procesu pritom není pouze navrhnout konkrétní strategii a projekty, které ji budou naplňovat, ale také organizační strukturu, jak bude o strategiích a projektech rozhodováno, jak budou prosazovány (realizovány) a evaluovány.

V souvislosti s hledáním nových př́stupů ke strategickému plánování měst a obcí bychom zároveň hledat odpovědi na následující otázky:

- Jakou roli hraje strategické plánování v rozvoji měst, resp. v rámci strategických rozhodovacích procesů ve městech?

- Kdo vlastně ve městech plánuje? Jaká je role plánovačů, politiků, ekonomických subjekti̊, neziskových organizací a občanské veřejnosti?

- Jaké jsou nejvhodnější formy organizace plánovacích procesů ve městech? Jak do nich zapojit aktéry z podnikatelského a občanského sektoru? Jak v podmínkách pluralitní společnosti 
vůbec koordinovat a integrovat rozdílné zájmy a potřeby veřejných a soukromých aktérů? Musí být vždy nositelem plánovacích kompetencí organizace veřejné správy?

- Jaké mají česká města praktické zkušenosti se strategickým plánováním? Jak ho chápou? Jaká mají očekávání? Jaké problémy či dilemata v souvislosti se strategickým plánování řeší? Jaké existují vazby mezi tvorbou rozvojových strategií, jejich realizací a evaluací?

- Jakou roli při tvorbě strategií pro města sehrávají procesy kolektivního učení?

- Jaká je efektivita strategického plánování rozvoje měst a jak ji hodnotit? Jaké jsou faktory úspěšnosti?

- Proč nestačí pouze vytvářet strategické plány pro města? Za jakých podmínek je smysluplné plánovat a jaké formy plánování jsou v podmínkách měst nejefektivnější? Jaké jsou př́ípadné alternativní (neplánovité) př́istupy k rozvoji měst.

\section{Literatura}

[1] ALBRECHTS, L. Strategic (spatial) planning reexamined. Environment and Planning B: Planning and Design, 2004, Vol. 31, s. 743-758.

[2] ARCHIBUGI, F. Planning Theory. From the Political Debate to the Methodological Reconstruction. Milano, 2008.

[3] FALUDI, A. The Performance of Spatial Planning. Planning Practice and Research, 2000, Vol. 15 (4), s. 299-318.

[4] HEALEY, P. Urban Complexity and Spatial Strategies. Towards a realational planning for our times. London, 2007.

[5] JEŽEK, J. (2011a). Plánování rozvoje měst a regionů. Vývoj teoretických př́stupů. In Višegrád, 2011, 2 (1), s. 61-72.

[6] JEŽEK, J. (2011b). Problémy strategického plánování rozvoje měst v České republice. Kritická analýza. In XIV. mezinárodni kolokvium o regionálních vědách. Sborník př́spěvků. Brno: Masarykova univerzita, 2011, s. 161-168.

[7] JEŽEK, J. a kol. Budováni konkurenceschopnosti obcí, měst a regionů. Plzeň, 2007.

[8] LUHMANN, N. Politische Planung - Aufsätze zur Soziologie von Politik und Verwaltung. Wiesbaden, 1971.

[9] MinTZBERG, H. et al. Strategy Process. Concepts, Contexts, Cases. Upper Sadle River (NJ), 2003.

[10] MMR. Účelová právni analýza samosprávných kompetencí obcí v oblasti plánování a realizace rozvojových aktivit obcí. Pro Ministerstvo pro místní rozvoj zpracovaly firmy GaREP, spol. s .r.o. a e-Rozvoj.cz, 2012. Dostupné z: <http://www.mmr.cz/getmedia/def4e459-425d-44d8-bde1062e3ba1c737/1-a2-UCELOVA-PRAVNI-ANALYZA_ariel>.

[11] NEWMANN, P. Strategic Spatial Planning: Collective Action and Moments of Opportunity. European Planning Studies, 2008, 16 (10), s. 1371-1383.

[12] SELLE, K. Stadtentwicklung aus Governance Perspektive. PNDonline II/2008, s. 1-15.

[13] WIECHMANN, T. Planung und Adaptation. Strategieentwicklung in Regionen, Organisationen und Netzwerken. Dortmund, 2008.

Př́spěvek byl zpracován v rámci grantu č. WD-19-07-1 Ministerstva pro místní rozvoj ČR „Konkurenceschopnost malých měst $v \check{C} R “$. 